\title{
THE IMPACT OF PEDRO CAMERON IN BRAZILIAN MUSIC
}

\section{Abstract}

\section{Djalma de Campos Gonçalves Júnior (IC)}

This study aimed at searching for the impacts of the composer, classical guitarist and music educator Pedro Bueno Cameron (Santo André, 1949). He has performed great musical activity in the state of São Paulo since the 1970s, with significant recognition in music business. His professional life can divided into three lines of action, the first about his activities as a teacher, the second related to his work as a composer and the last about his role as a performer of pieces for classical guitar.

Key words: Cameron, Oral History, Brazilian Music.

\section{Introduction}

Pedro Bueno Cameron is responsible for being part the dividing mark of the teaching of musical instruments in Brazil. As a musical educator, along with other teachers of the Dramatic and Musical Conservatory "Dr. Carlos de Campos" of the city of Tatuí - SP, developed new methodologies that were responsible for countering the individual teaching tool in favor of collective education. As a composer, he was awarded in national and international festivals, and studied with Gyorgy Ligeti's and Alberto Ginastera's students. As a interpreter, he currently has an intensive activity in the State of São Paulo, playing a key role as a promoter of symphony works and solo guitar.

\section{Results and Discussion}

Some more relevant information about the research were as the initial project, which was born in Tatuí - SP, managed to get success and positive results so that it was possible to influence several other cities in the state of São Paulo, as a Sorocaba and Rio Claro, cities that never had free music schools or symphony orchestras. The project made it possible to offer the population several instrument classes where a lot of students professionalized and now integrate orchestras across Brazil.

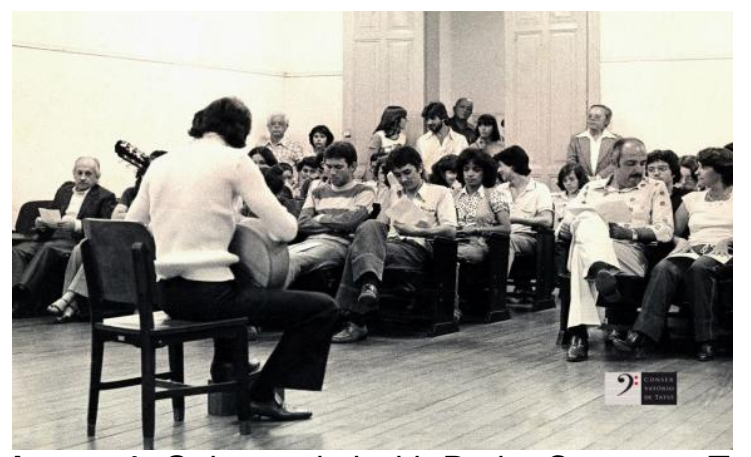

Image 1. Guitar recital with Pedro Cameron, Tatuí - SP, 1970.

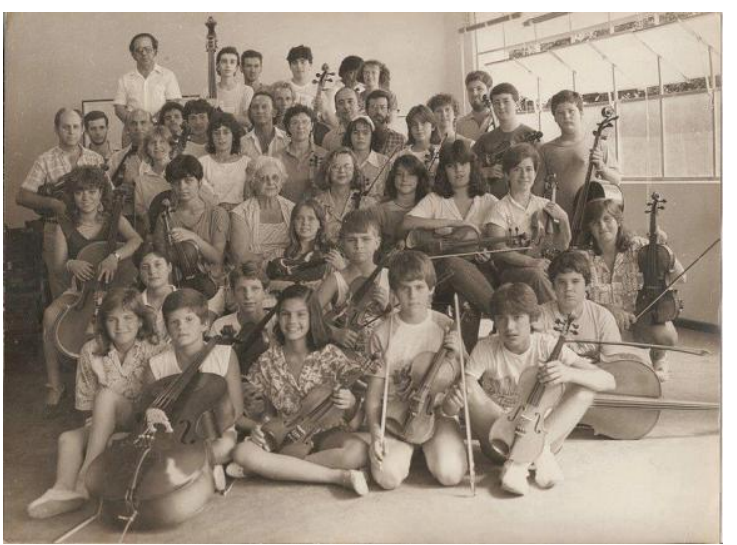

Image 2. Second class of school of music "Fábio Marasca", Rio Claro, 1985.

\section{Conclusions}

We conclude that participation of Cameron in Brazilian music, especially since 1970, was intense and with great contributions. His participation in the setting of musical education became critical in a period of changes as part of the responsible names for the dividing mark in the teaching tools collectively in Brazil and finally, his role as a composer was responsible for the creation of a new tutoring method for students, and as a composer he produced works of aesthetic vanguard, being awarded in several competitions and festivals, both national and international.

\section{Acknowledgement}

Serviço de Apoio ao Estudante - UNICAMP.

PEROTTO, L. L. A obra para violão de Pedro Cameron:

Características idiomáticas e estilísticas. Goiânia: Universidade Federal de Goiás, 2007. 